\title{
Use of foliar fertilizers as attenuators of injuries caused by glyphosate drift in young coffee plantations
}

\author{
Ana Luisa Lucca Gonçalves ${ }^{1}$, Gustavo Antônio Mendes Pereira ${ }^{1 *} \mathbb{(}$, Larissa Aparecida Silva ${ }^{1}(\mathbb{B})$, Deivide Patrik Alves ${ }^{1}(\mathbb{B}$, \\ Laís Franchini Pucci ${ }^{\mathbb{1}}$, Victor Afonso Reis Gonçalves ${ }^{1}$, Marcelo Rodrigues dos Reis ${ }^{1}$ (i)
}

${ }^{1}$ Universidade Federal de Viçosa/UFV, Rio Paranaíba, MG, Brasil

Contact authors: analuisalucca@hotmail.com, gustavogamp@hotmail.com, larissaufv97@gmail.com, deividepatrikalves123@gmail.com, laisfpucci@gmail.com, victor.a.r.goncalves@gmail.com, marceloreis@ufv.br

Received in May 15, 2020 and approved in December 3, 2020

\begin{abstract}
Glyphosate is the most used product for weed control in young coffee planting rows. The application is carried out in a directed way, avoiding the contact of the product with the crop. However, drift and consequent plant injuries frequently occur. An alternative to reduce these injuries is the use of attenuators capable of reducing the negative effects caused by this herbicide. Therefore, the objective of this study is to verify the efficiency of foliar fertilizers (Fertiactyl Pós ${ }^{\circ}$ and $\mathrm{Crop}^{+}$) as attenuators of the toxic effects caused by the use of glyphosate in the coffee crop. Thus, coffee seedlings were subjected to different doses of the mixture of Fertiactyl Pós ${ }^{\circ}$ with glyphosate and Crop ${ }^{+}$with glyphosate. The treatments were applied on top of the plants. The percentage of coffee intoxication was evaluated at 14,21, 28, 35, 42 and 90 days after application. At 90 days after application, height, leaf area and shoot and root dry matter were evaluated. Higher doses of glyphosate ( 1.44 and $\left.2.88 \mathrm{~kg} \mathrm{ha}^{-1}\right)$ without the use of attenuators caused intoxication levels close to $80 \%$ at 28 and 90 DAA. The use of Fertiactyl Pós ${ }^{\circ}$ and Crop $^{+}$reduced the injuries caused by the application of glyphosate, regardless of the dose of herbicide and fertilizers, but with different levels of action. All the morphological variables measured suffered a negative action with the isolated use of glyphosate, with a tendency to recover when the attenuators were applied. It is concluded that the two attenuators were efficient in suppressing the deleterious effects of glyphosate on coffee plants affected by this herbicide. For $0.720 \mathrm{~kg} \mathrm{ha}^{-1}$ of glyphosate, the dose most used in the field, $8 \mathrm{~L} \mathrm{ha}^{-1}$ is recommended for Fertiactyl Pós $s^{\circ}$ and $4 \mathrm{~L} \mathrm{ha}^{-1}$ for Crop ${ }^{+}$.
\end{abstract}

Key words: Coffea arabica; Crop+; Fertiactyl Pós ${ }^{\circledR}$; Injury; Weed control.

\section{INTRODUCTION}

Coffee (Coffea sp.) is a very important commodity for the national economy (Companhia Nacional de Abastecimento CONAB, 2019) and Brazil is the world's largest producer (Empresa Brasileira de Pesquisa Agropecuária Ministério da Agricultura, Pecuária e Abastecimento - EMBRAPA, 2018). Such importance and demand require an effective management to guarantee and increase yield, thus making phytosanitary management necessary, with the control of diseases, pests and weeds.

Since weeds cause losses (most of the times not as notorious in the short term, such as the attack of pests and diseases), they frequently present a less intensive management than necessary (Pucci et al., 2019; Alcântara et al., 2009). One point that complicates this control is the phenology of coffee, with a slow initial growth (Gomes et al., 2019; França et al., 2013; Silva et al., 2008), once it is a crop that takes a long time to totally shade the planting row, consequently reducing the competitive capacity of weeds (Magalhães et al., 2012; Meschede et al., 2004).

Species such as Brachiaria decumbens, Digitaria horizontalis, Brachiaria plantaginea and Mucuna aterrima, in coexistence with coffee seedlings for 90 days, show a significant decrease in crop growth and development (Fialho et al., 2011), and glyphosate is the main control alternative adopted (Matos et al., 2013).

Glyphosate is non-selective, that is, its contact with coffee plants can cause injuries that affect yield (França et al., 2010). Thus, there are several reports of drift in coffee plantations during application on the streets, showing intoxications such as the appearance of chlorotic, small and brittle leaves (Carvalho et al., 2014; Yamashita et al., 2013; Malavolta, 2006). Therefore, it is necessary to search for ways to mitigate these intoxications, without the need to suspend the use of herbicides.

The hypothesis of this study is that products as Fertiactyl Pós ${ }^{\circledR}$ and Crop $^{+}$have the potential to mitigate the toxic effects caused by glyphosate drift in coffee plants, as found by Machado et al., 2017a; Machado et al., 2017b; Machado et al., 2017c, in eucalyptus. It is expected that, in the near future, coffee producers will be able to carry out the initial management without fear of damaging their crops with intoxication of non-selective herbicides, without losses in development and yield.

Therefore, the objective of this research was to verify the efficiency of foliar fertilizers Fertiactyl Pós and $\mathrm{Crop}^{+}$, as attenuators of the toxic effects caused by glyphosate drift in young coffee crop. 


\section{MATERIAL AND METHODS}

The experiment with the two foliar fertilizers (Fertiactyl Pós and Crop $^{+}$) were carried out in different assays, but with the same methodology. The assays were conducted in a greenhouse at Universidade Federal de Viçosa - Rio Paranaíba Campus, from March to June 2019. For this purpose, $8 \mathrm{dm}^{3}$ pots were used and filled with Red-Yellow Latosol (LVAd) (Table 1), fertilized with Super Simples at a dose of $180 \mathrm{~kg} \mathrm{ha}^{-1}$. In each pot, a 'Catucaí Vermelho' coffee seedling was transplanted, constituting an experimental unit. The seedlings were standardized as to the size and number of leaves.

Table 1: Chemical analysis of the soil used in the experiment.

\begin{tabular}{ccccc}
\hline $\begin{array}{c}{ }^{1} \text { M.O.S } \\
\left(\mathrm{g} . \mathrm{dm}^{3}\right)\end{array}$ & $\begin{array}{c}{ }^{2} \mathrm{C} . \mathrm{O} . \mathrm{T} \\
\left(\mathrm{g} . \mathrm{dm}^{3}\right)\end{array}$ & $\begin{array}{c}{ }^{3} \mathrm{pH} \\
\left(\mathrm{CaCl}_{2}\right)\end{array}$ & ${ }^{3} \mathrm{pH}$ & $\begin{array}{c}{ }^{4} \mathrm{CTC} \\
\left(\mathrm{mmol}_{\mathrm{c}} \mathrm{dm}^{3}\right)\end{array}$ \\
\hline 0.31 & 18 & 5.8 & 6.52 & 88.5 \\
\hline
\end{tabular}

${ }^{1}$ M.O.S.: soil organic matter; ${ }^{2}$ C.O.T.: total organic carbon; ${ }^{3} \mathrm{pH}$ : hydrogen potential; ${ }^{4} \mathrm{CTC}$ : cation exchange capacity.

The first experiment consisted of applying four doses of glyphosate alone (360; 720; 1440 and $2280 \mathrm{~g} \mathrm{ha}^{-1}$ a.e.), and four doses of glyphosate associated with different doses of Fertactyl Pós (0.36 kg ha-1 a.e.; + $1.0 \mathrm{~L} \mathrm{ha}^{-1} ; 0.72 \mathrm{~kg} \mathrm{ha}^{-1}$ a.e. $+2.0 \mathrm{~L} \mathrm{ha}^{-1} ; 1.44 \mathrm{~kg} \mathrm{ha}^{-1}$ a.e. $+4.0 \mathrm{~L} \mathrm{ha}^{-1} ; 2.88 \mathrm{~kg} \mathrm{ha}^{-1}$ a.e. $+8.0 \mathrm{~L} \mathrm{ha}^{-1}$ ), in addition to a control, without application of products. The design was completely randomized (CRD), with three replications.

The second experiment followed the same pattern: four isolated doses of glyphosate (0.36, 0.72, 1.44 and $2.88 \mathrm{~kg} \mathrm{ha}^{-1}$ a.e.) were applied, and four doses of glyphosate associated with $\mathrm{Crop}^{+}\left(0.36 \mathrm{~kg} \mathrm{ha}^{-1}\right.$ a.e. $+0.5 \mathrm{~L} \mathrm{ha}^{-1} ; 0.72 \mathrm{~kg} \mathrm{ha}^{-1}$ a.e. +1.0 $\mathrm{L} \mathrm{ha}^{-1} ; 1.44 \mathrm{~kg} \mathrm{ha}^{-1}$ a.e. $+2.0 \mathrm{~L} \mathrm{ha}^{-1} ; 2.88 \mathrm{~kg} \mathrm{ha}^{-1}$ a.e. $+4.0 \mathrm{~L}$ $\mathrm{ha}^{-1}$ ), in addition to a control, without the herbicide. The design was completely randomized (CRD), with three replications.

Spraying was carried out with a costal electric sprayer, containing three dual fan tips, with an adjusted flow rate of $200 \mathrm{~L} \mathrm{ha}^{-1}$.
At 14, 21, 28, 35, 42 and 70 days after application (DAA), plant intoxication, plant height, number of leaves, number of nodes and expanded leaf diameter were evaluated from the third pair of leaves. For the obtention of the percentage of intoxication, scores ranging from zero (absence of symptoms) to 100 (plant death) were attributed (Sociedade Brasileira da Ciência de Plantas Daninhas - SBCPD, 1995) (Table 2).

In the last evaluation, the leaf area of coffee plants was measured; in addition, shoots and roots were collected. The samples were weighed on a scale to two decimal places, for the obtention of root and shoot fresh matter.

Subsequently, these samples were dried in a forced air oven at $68^{\circ} \mathrm{C}$ for 48 hours. Again, they were weighed, but for the obtention of root and shoot dry matter.

Injuries to plants caused by the herbicide were evaluated by comparison with control plants that did not receive herbicide application. Injury data on coffee plants were analyzed descriptively and plotted using the SigmaPlot software for Windows (Version ${ }^{\circledR} 12.0$ ), the data being plotted in bar graphs and the other data were submitted to regression analysis; in case of significance, the means were adjusted to regression equations. The significance of the equation parameters was tested in the Minitab $^{\circledR}$ 16.2.1 software and the graphs were plotted in the SigmaPlot for Windows (Version ${ }^{\circledR} 12.0$ ).

\section{RESULTS}

The use of Fertiactyl Pós and Crop ${ }^{+}$reduced the injuries caused by the application of glyphosate, regardless of the dose of herbicide and fertilizers, but with different levels of action (Figures 1 and 2). It is observed that there was a trend of direct relationship between the increase in the dose of fertilizers with the smallest injuries, an effect less pronounced when the highest glyphosate doses were used.

The accumulation of dry matter in the shoot and roots was linearly reduced when the seedlings were subjected to increasing applications of glyphosate doses in the absence of attenuators (Figure 3, A, B, C and D). The increase in the dose of Fertiactyl Pós and Crop $^{+}$linearly reduced the effects of glyphosate on the accumulation of dry matter.

Table 2: Score scale for the visual assessment of intoxication in coffee plants.

\begin{tabular}{|c|c|c|}
\hline Concept & Score & Observation \\
\hline Very mild & $0-5$ & Weak or barely evident symptoms. Score zero when there are no changes in the plant. \\
\hline Mild & $6-10$ & Clear, low-intensity symptoms. \\
\hline Moderate & $11-20$ & Clear symptoms, more intense than in the previous class. \\
\hline Acceptable & 21-35 & Pronounced symptoms, but fully tolerated by the plant. \\
\hline Worrisome & $36-45$ & More drastic symptoms than in the previous class, but still recoverable. \\
\hline High & $46-60$ & Irreversible damage, with drastic reduction in plant development. \\
\hline Very high & $61-100$ & Very severe, irreversible damage. Score one hundred for plant death. \\
\hline
\end{tabular}

Adapted from the SBCPD (1995). 


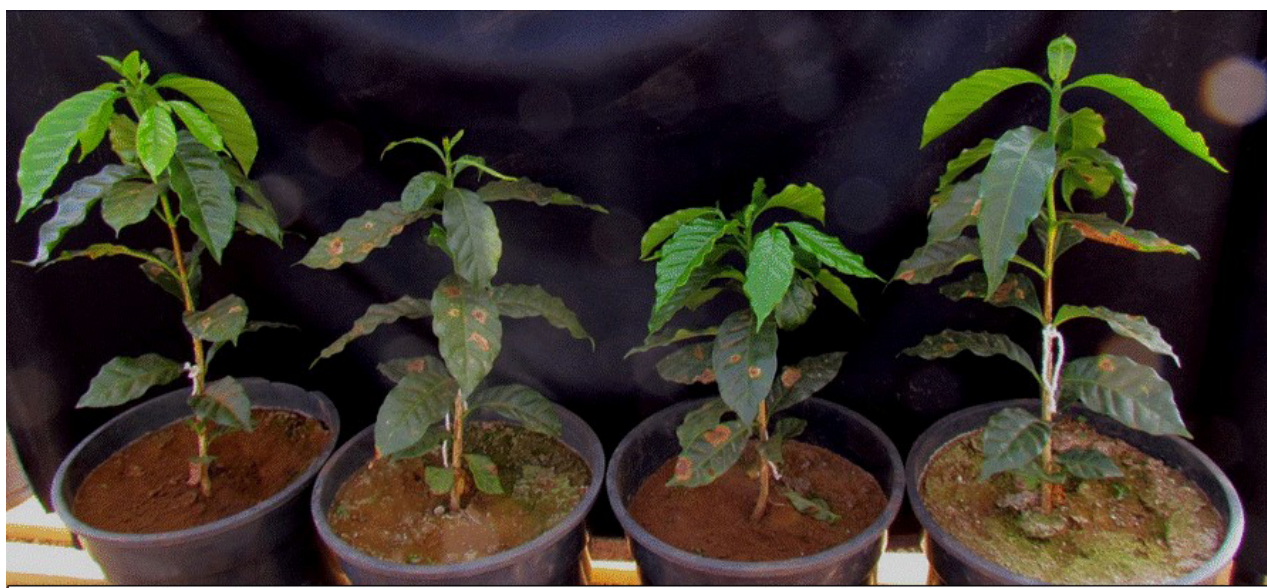

Control Glyphosate $\left(0.36 \mathrm{~kg} \mathrm{ha}^{-1}\right)$ Glyphosate $\left(0.36 \mathrm{~kg} \mathrm{ha}^{-1}\right)$ Glyphosate $\left(0.36 \mathrm{~kg} \mathrm{ha}^{-1}\right)$

GZ (1 L ha-1)

Crop+ $\left(0.5 \mathrm{~L} \mathrm{ha}^{-1}\right)$

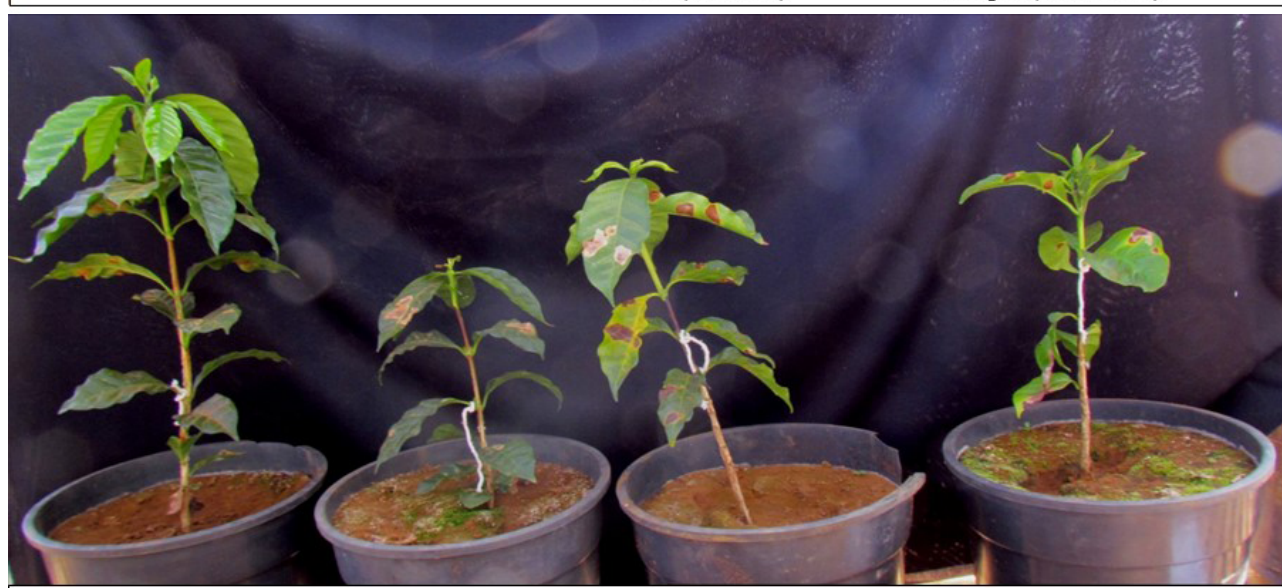

Control Glyphosate $\left(0.72 \mathrm{~g} \mathrm{ha}^{-1}\right)$ Glyphosate $\left(0.72 \mathrm{~kg} \mathrm{ha}^{-1}\right)$ Glyphosate $\left(0.72 \mathrm{~kg} \mathrm{ha}^{-1}\right)$

$\mathrm{GZ}\left(2 \mathrm{~L} \mathrm{ha}^{-1}\right)$

Crop $+\left(1 \mathrm{~L} \mathrm{ha}^{-1}\right)$

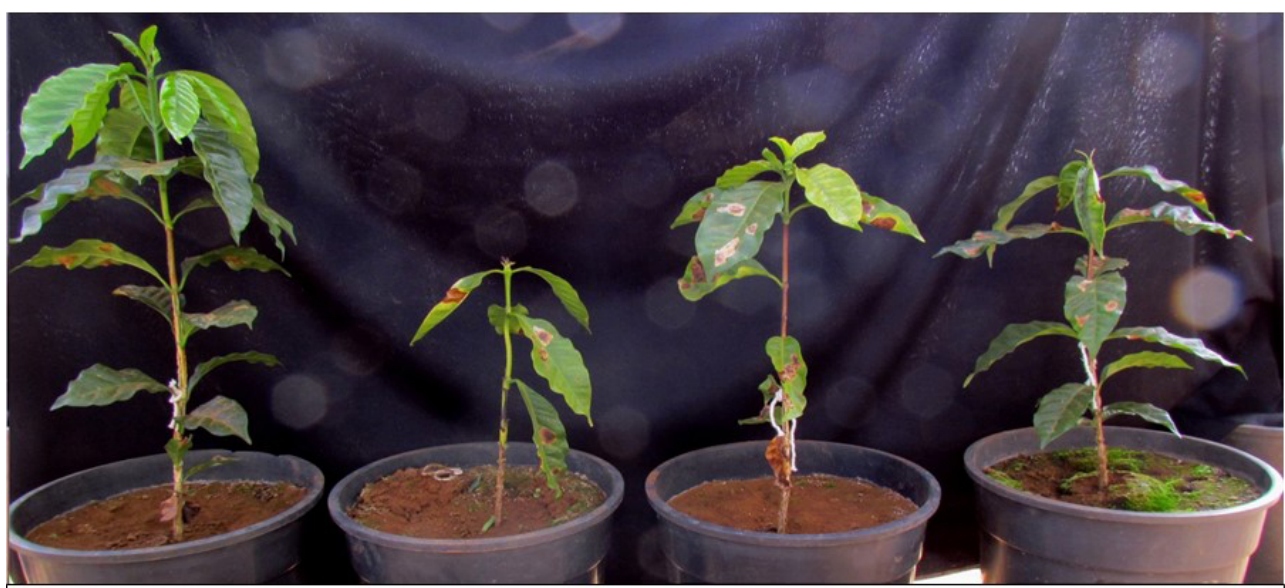

Control Glyphosate $\left(1.44 \mathrm{~g} \mathrm{ha}^{-1}\right)$ Glyphosate $\left(1.44 \mathrm{~kg} \mathrm{ha}^{-1}\right)$ Glyphosate $\left(1.44 \mathrm{~kg} \mathrm{ha}^{-1}\right)$

GZ (4 L ha $\left.{ }^{-1}\right)$

Crop $+\left(2 \mathrm{~L} \mathrm{ha}^{-1}\right)$

Figure 1: Coffee plants treated with the mixture of glyphosate + Fertiactyl Pós and glyphosate + Crop $^{+}$at different doses at 28 days after application (A, B, C and D) at 82 DAA. 


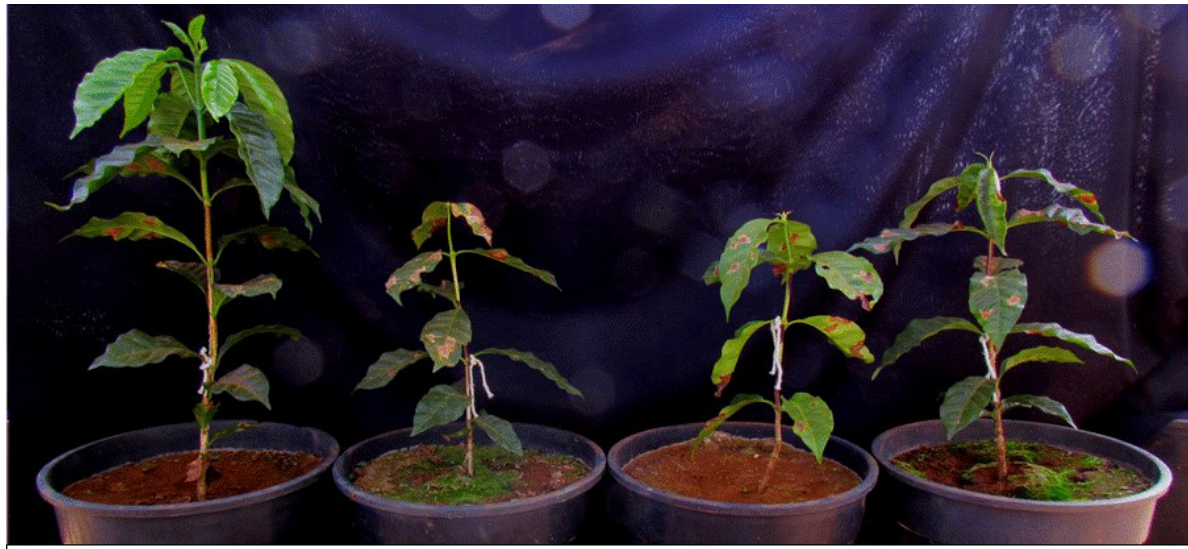

Control Glyphosate $\left(2.88 \mathrm{~g} \mathrm{ha}^{-1}\right)$ Glyphosate $\left(2.88 \mathrm{~kg} \mathrm{ha}^{-1}\right)$ Glyphosate $\left(2.88 \mathrm{~kg} \mathrm{ha}^{-1}\right)$

GZ (8 L ha $\left.{ }^{-1}\right)$

Crop+ $\left(4 \mathrm{~L} \mathrm{ha}^{-1}\right)$

Figure 1: Continuation.
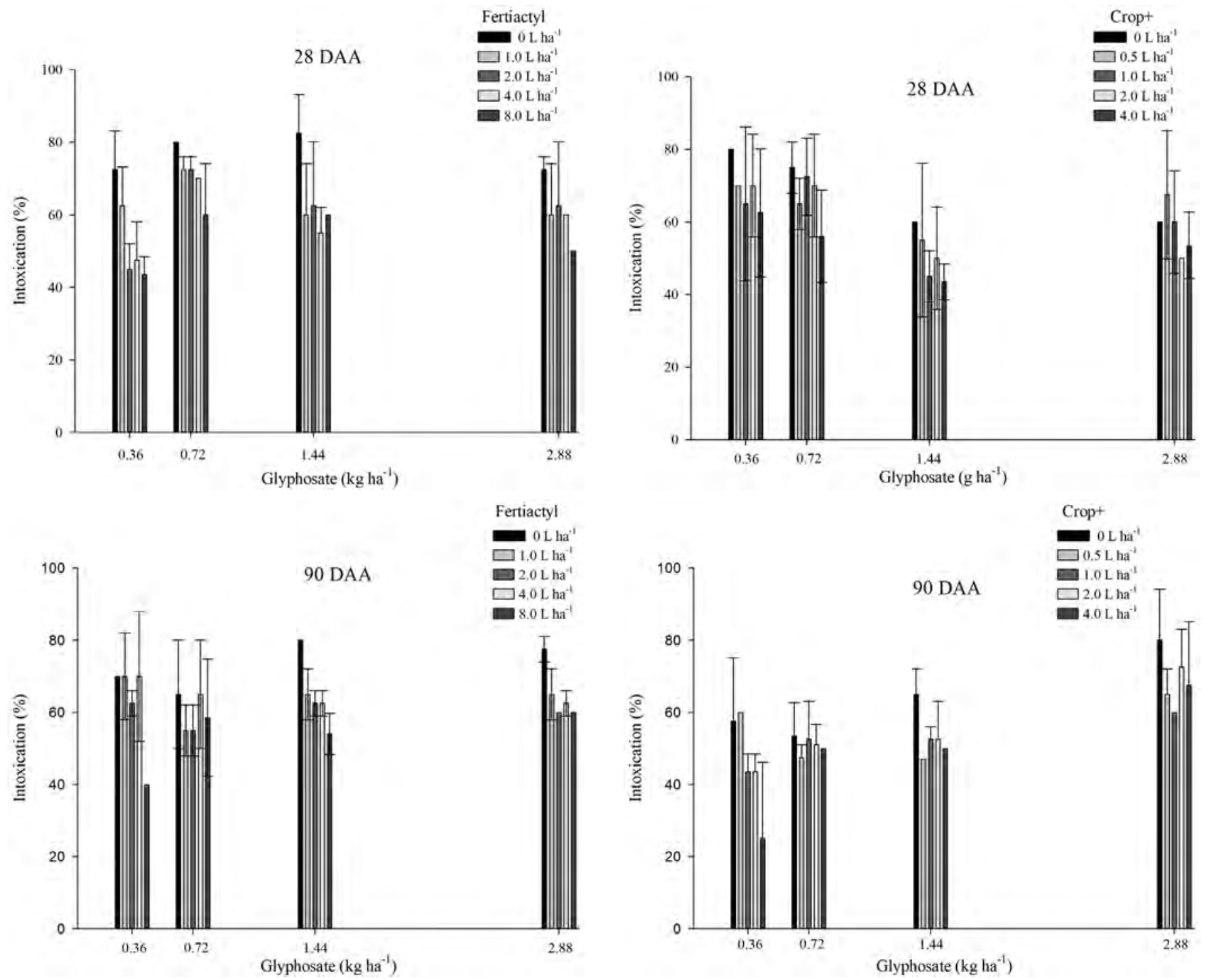

Figure 2: Intoxication percentage of coffee plants submitted to the application of glyphosate ( $\left.\mathrm{kg} \mathrm{ha}^{-1}\right)$ in mixture with Fertiactyl Pós and $\mathrm{Crop}^{+}$at 28 and 82 days after application. Bars represent mean \pm standard deviation $(n=3)$. 

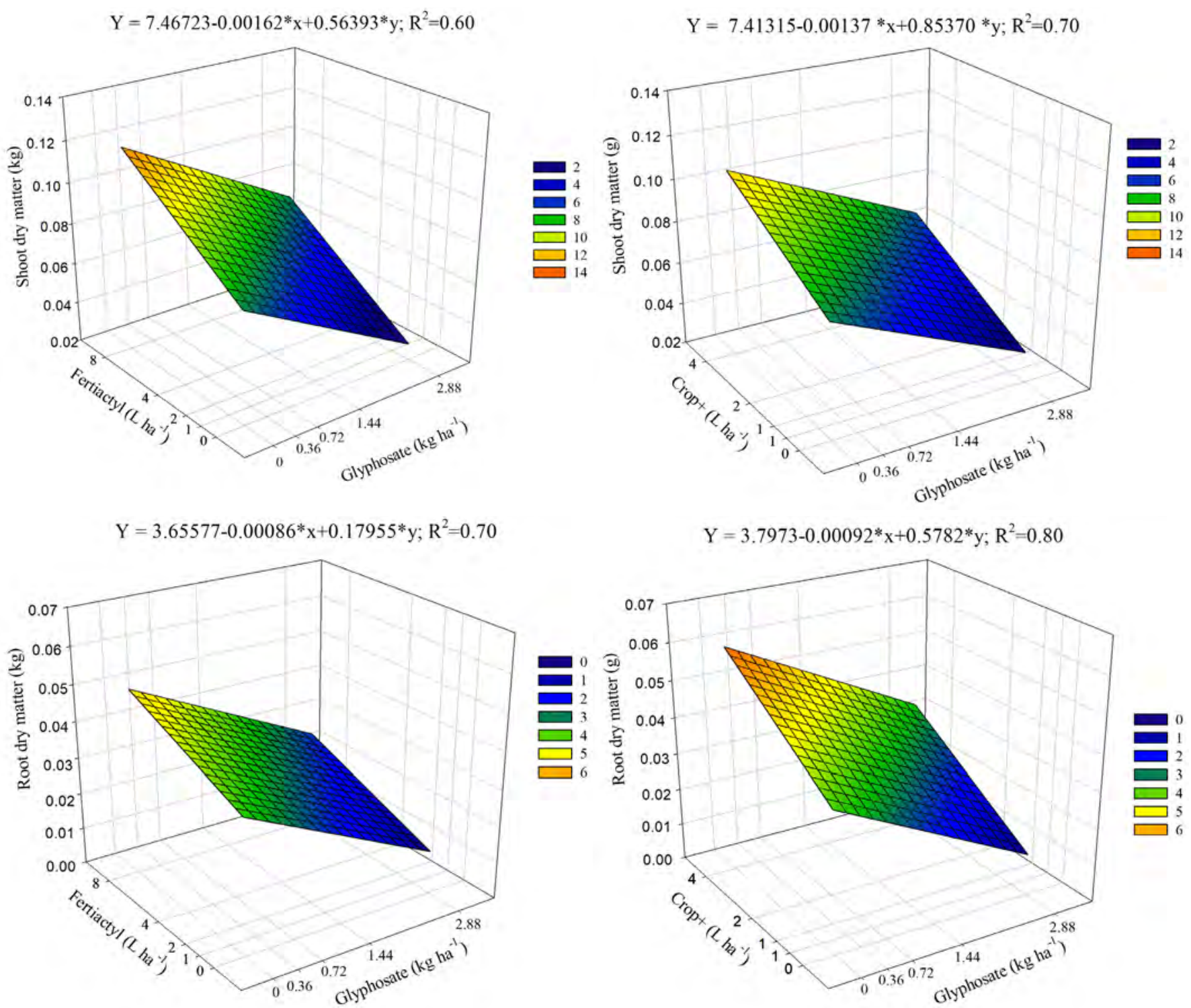

Figure 3: Estimates of shoot $(A$ and $B)$ and root $(C$ and $D)$ dry matter of coffee plants submitted to the application of glyphosate in mixture with Fertiactyl Pós and $\mathrm{Crop}^{+}$at 90 DAA.

Estimates of leaf area and plant height also followed the dry matter trend, with Fertiactyl Pós and $\mathrm{Crop}^{+}$reducing the negative effects of glyphosate on coffee plants (Figure 4, $\mathrm{A}, \mathrm{B}, \mathrm{C}$ and D). The use of Crop + results in a larger leaf area than Fertiactyl Pós. It can be observed that, with the use of $2.88 \mathrm{~kg} \mathrm{ha}^{-1}$ of glyphosate and $0.008 \mathrm{~kg} \mathrm{ha}^{-1}$ and $0.004 \mathrm{~kg}$ $\mathrm{ha}^{-1}$ of Fertiactyl Pós and Crop ${ }^{+}$, respectively, the leaf area of Fertiactyl Pós is close to $0.0004 \mathrm{~m}^{2}$, against $0.006 \mathrm{~m}^{2}$ of Crop ${ }^{+}$. For both, at a dose of $1.44 \mathrm{~kg} \mathrm{ha}^{-1}$ of glyphosate, the dose of attenuators that led to the highest leaf area index was $8 \mathrm{~L} \mathrm{ha}^{-1}$ for Fertiactyl Pós and $4 \mathrm{~L} \mathrm{ha}^{-1}$ for Crop ${ }^{+}$.

\section{DISCUSSION}

Machado et al. (2017) observed injury levels below $20 \%$ in eucalyptus seedlings submitted to different doses of
Fertiactyl Pós mixed with $1.44 \mathrm{~kg} \mathrm{ha}^{-1}$ of glyphosate at 49 DAA. In this study, higher doses of glyphosate (1.44 and 2.88 $\mathrm{kg} \mathrm{ha}^{-1}$ ), without mixing with the stress attenuators Fertiactyl Pós and $\mathrm{Crop}^{+}$, showed intoxication levels close to $80 \%$ at 28 and 90 DAA (Figure 2). França et al. (2010) report that doses of glyphosate from $0.2304 \mathrm{~kg} \mathrm{ha}^{-1}$ already show symptoms of injuries and doses close to $0.4608 \mathrm{~kg} \mathrm{ha}^{-1}$ reduce the content of $\mathrm{P}$ in the plant by $19.38 \%$. Thus, it is important to observe that high doses of glyphosate are extremely harmful to coffee since, in addition to compromising its development and causing injuries, they decrease significant amounts of essential nutrients.

Similar results were found by Machado (2017a), to the accumulation of dry matter in the shoot and roots, where it was observed that the accumulation of dry matter of leaves, stem, roots and total in eucalyptus decreased as glyphosate 

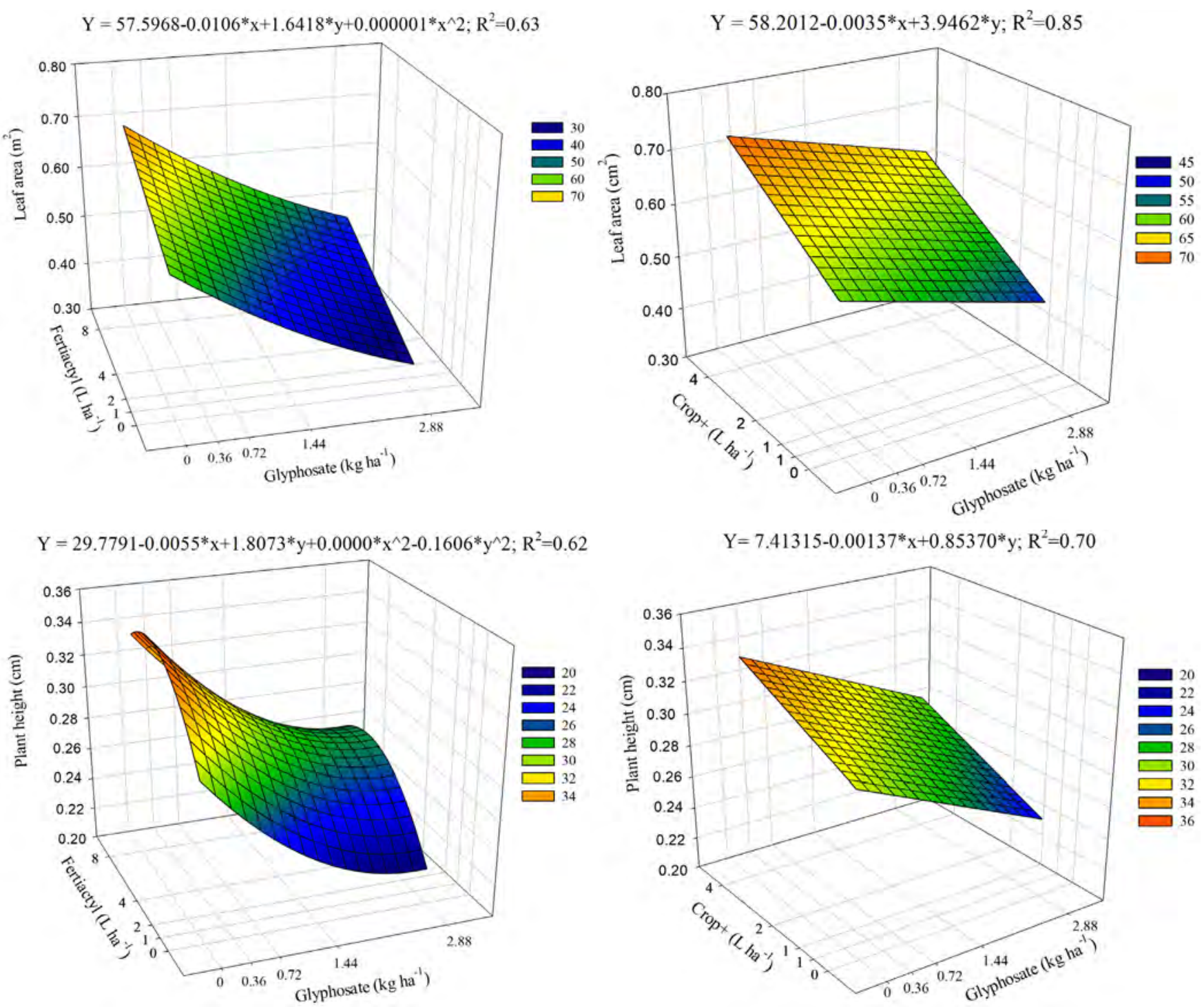

Figure 4: Estimates of leaf area (A and B) and height (C and D) of cottee plants submitted to the applıcatıon of glyphosate in mixture with Fertiactyl Pós and Crop $^{+}$at 90 DAA.

increased but, in the presence of Fertiactyl Pós, these effects were reduced. It is possible to notice that, in relation to shoot dry matter, the increase in the dose of Fertiactyl Pós was greater than the corresponding dose of $\mathrm{Crop}^{+}$. Regarding dry matter accumulation in the roots, the opposite occurs, there was a greater increase in the dry matter accumulation at higher doses of $\mathrm{Crop}^{+}$compared to Fertiactyl Pós. França et al. (2010) explained that the behavior of the root system of coffee plants after exposure to glyphosate is due to the translocation of carbohydrates from the roots for plant recovery.

França et al. (2010), also proved that the doses of attenuators necessary to reduce the harmful effects of glyphosate on coffee vary according to the amount of the herbicide that reaches the plant. There was also a reduction in the leaf area of Arabica coffee with an increase in the dose of glyphosate (Schrübbers et al., 2014). Plant height followed the tendency of leaf area, showing higher height in relation to the plants affected by glyphosate in mixture with $\mathrm{Crop}^{+}$. Nascimento et al. (2019) also carried out a study on the use of Fertiactyl Pós as an attenuator of injuries caused in coffee seedlings, with results similar to those observed in this study for the variables plant height, leaf area and dry matter. The author also reports the presence of overgrowth caused by the herbicide, which was mitigated with the use of Fertiactyl Pós.

In this study, it was possible to prove the efficiency of Fertiactyl Pós in reducing the harmful effects of glyphosate drift in coffee seedlings, adding information to the studies by Nascimento et al. (2019) in coffee and Machado et al. (2017a, 2017b, 2017c) in eucalyptus. It also proved the same attenuation capacity when the seedlings 
were submitted to $\mathrm{Crop}^{+}$, an action never before tested in coffee crop. In addition, the study compared the efficiency of the two products. The results of this research are an important contribution to the future use of these attenuators in the field, requiring further studies to prove what are the mechanisms involved in the mitigating action of these products in coffee seedlings.

\section{CONCLUSIONS}

The attenuators Fertiactyl Pós and Crop ${ }^{+}$, applied in mixture with glyphosate, have the potential to be used to protect the damage caused by glyphosate in young coffee plants. For $0.720 \mathrm{~kg} \mathrm{ha}^{-1}$ i.a. of glyphosate, the dose most used in the field, $8 \mathrm{~L} \mathrm{ha}^{-1}$ is recommended for Fertiactyl Pós and $4 \mathrm{~L} \mathrm{ha}^{-1}$ for Crop ${ }^{+}$.

\section{ACKNOWLEDGMENTS}

The authors would like to thank Capes, and CNPq for the support in the conduction of this study.

\section{REFERENCES}

ALCÂNTARA, E. N.; NÓBREGA, J. C. A.; FERREIRA, M. M. Métodos de controle de plantas daninhas no cafeeiro afetam os atributos químicos do solo. Ciência Rural, 39(3):749-757, 2009.

CARVALHO, F. P. et al. Deriva de glyphosate afeta a associação micorrízica arbuscular em cafeeiro. Planta daninha, 32(4):783-789, 2014.

\section{COMPANHIA NACIONAL DE ABASTECIMENTO -} CONAB. Acompanhamento da safra brasileira de café. 2020. Brasília, DF: Conab, Available in: <https:// www.conab.gov.br/info-agro/safras/cafe >. Access in: November, 12, 2020.

\section{EMPRESA BRASILEIRA DE PESQUISA} AGROPECUÁRIA MINISTÉRIO DA AGRICULTURA, PECUÁRIA E ABASTECIMENTO - EMPRAPA. Valor bruto da produção. 2020. Brasília, DF: Embrapa. Available in: <https://www.embrapa.br/busca-denoticias/-/noticia/56084554/producao-dos-cafes-do-brasilatinge-6162-milhoes-de-sacas-de-60kg-em-2020-volume25-maior-que-2019>. Access in: November, 04, 2020.

FRANÇA, A. C. et al. Teores de nutrientes em cultivares de café arábica submetidos à deriva de glyphosate. Planta daninha, 28(4):877-885, 2010.

FRANÇA, A. C. et al. Deriva simulada do glyphosate em cultivares de café Acaiá e Catucaí. Planta daninha, 31(2):443-451, 2013.
GOMES, C. A. et al. Indaziflam application in newly transplanted arabica coffee seedlings. Coffee Science, 14(3):373-381, 2019.

MACHADO, M. S. et al. Use of liquid fertilizer to reduce the phytotoxic effects of glyphosate on eucalyptus. Revista Caatinga, 30(3):730-737, 2017a.

MACHADO, M. S. et al. Protective effect on eucalyptus plants and signal grass control with a tank mixture of glyphosate and liquid fertilizer. Planta Daninha, 35(1):18, 2017b.

MACHADO, M. S. et al. Fertiactyl Pós ${ }^{\circledR}$ como protetor do eucalipto submetido à aplicação de glyphosate. Revista Brasileira de Ciências Agrarias, 12(2):194-201, 2017c.

MAGALHÃES, C. E. O. et al. Seletividade e controle de plantas daninhas com oxyfluorfen e sulfentrazone na implantação de lavoura de café. Planta Daninha, 30(3):607-616, 2012.

MALAVOLTA, E. Manual de nutrição mineral de plantas. São Paulo, São Paulo: Agronômica ceres, 2006. 638p.

MATOS, C. C. et al. Características fisiológicas do cafeeiro em competição com plantas daninhas. Bioscience Journal, 29(5):1111-1119, 2013.

NASCIMENTO, J. L. M. et al. Tolerância de plantas jovens de café a herbicidas aplicados isoladamente ou em mistura com o fertilizante fertiactyl. Revista Brasileira de Herbicidas, 18(4): 1-8, 2019.

PUCCI, L. F. et al. Association of indaziflam and oxyfluorfen in coffee pre- transplantation. Coffee Science, 14(3):359365, 2019.

SCHRÜBBERS, L. C. et al. Glyphosate spray drift in Coffea arabica - Sensitivity of coffee plants and possible use of shikimic acid as a biomarker for glyphosate exposure. Pesticide Biochemistry and Physiology, 115(1):15-22, 2014.

SOCIEDADE BRASILEIRA DA CIÊNCIA DE PLANTAS DANINHAS - SBCPD. Procedimentos para instalação, avaliação e análise de experimentos com herbicidas. Londrina: SBCPD, 1995. 42p.

SILVA, A. A.; RONCHI, C. P. Manejo e controle de plantas daninhas em café. In: VARGAS, L.; ROMAN, E. S. (ed.). Manual de manejo e controle de plantas daninhas. Passo Fundo: Embrapa Trigo, p.417-475, 2008.

YAMASHITA, O. M. et al. Deriva simulada de herbicidas em mudas de Coffea canéfora. Scientia Agraria Paranaensis, 12(2):148-156, 2013. 